\title{
A LIBAHIZLALÁS NATURÁLIS ÉS ÖKONÓMIAI HATÉKONYSÁGA ELTÉRỎ NEVELÉSI IDŐ ESETÉN
}

\author{
Molnár Szilvia - Szőllősi László
}

\section{Összefoglalás}

A hazai viziszárnyas-ágazatot exportorientáltság jellemzi, a külkereskedelem nemzetgazdasági szempontból jelentös deviza-bevételi forrás. Az ágazat szereplöi számára nehézséget jelent, hogy a liba a felvevö országok piacain szezonális terméknek tekinthetö, ezért árérzékeny, kis volumenben értékesithetö. A lúdtermékek kereslete jelentös mértékben függ a fogyasztói szokásoktól, s miután az árakat a piac határozza meg, a tevékenység jövedelme részben attól függ, hogy a termelök milyen áron tudják értékesiteni a termékeiket. Így az árutermelés során koncentrálni kell a versenyképességre, solyan termékeket kell elóállitani, amelyek értékesithetöek a piacon. A tanulmány célja a libahizlalás termelési paramétereinek, illetve költség-és jövedelemviszonyainak vizsgálata eltérö hizlalási idö esetén, adott telep példáján keresztül. A vizsgált telep esetében a begyüjtött technológiai és ökonómiai adatok leiró statisztikai módszerekkel történö feldolgozását követöen, független kétmintás t-próba alkalmazásával vizsgáltuk a két hizlalási idö termelési és gazdasági adatai között kimutatható eltéréseket. Meghatároztuk továbbá a 14 hetes húsliba elöállitása esetében tapasztalható többletráfordítással elérhetö eredményváltozást a 9 hetes pecsenyeliba termelés ráforditásszintjéhez képest. Megállapitható, hogy amig a naturális hatékonysági mutatók értéke romlik a továbbhizlalással, addig a 9-14. hét többletráfordításai eredményeként növekszik az árbevétel és a jövedelem.

Kulcsszavak: libahizlalás, hizlalási idő, termelési költség, jövedelem, hatékonyság JEL: M11, Q12, Q13 


\title{
PHYSICAL AND ECONOMIC EFFICIENCY OF GEESE PRODUCTION IN DIFFERENT REARING PERIOD
}

\begin{abstract}
The domestic waterfowl sector is characterized by an export orientation, its importance is high in the national economy. It is difficult for operators in the sector that the goose is considered as a seasonal product on the markets of the participating countries, and therefore it is price-sensitive and can be sold in small volumes. The demand of goose products is highly dependent on consumer habits, whereas prices are determined by the market, so the income of activity depends in part on the price at which the producers can sell their products. Thus, in production, it is necessary to concentrate on competitiveness and produce products that can be marketed. The objective of this study is to analyse production parameters, as well as the cost and income situation of goose production in the case of different rearing period, through the example of given farm. After the processing of technological and economic data of the investigated farm using descriptive statistical methods, independent two-sample t-test was applied to find significant difference between production and economic parameters of the two rearing period. Furthermore, we determined the change in the profit of 14-week-old goose producing achieved by the additional costs compared to level of expenditurelinput level of producing 9-week-old goose. It can be concluded that while the physical efficiency indicators deteriorate by the further fattening, as a result of the additional costs between the $9^{\text {th }}$ and $14^{\text {th }}$ week the revenue and income are increasing.
\end{abstract}

Keywords: geese production, rearing period, production cost, profit, efficiency JEL: M11, Q12, Q13 


\section{Bevezetés}

A magyar baromfiágazat nemzetgazdasági szinten kiemelt jelentőségű. Az AVEC (2017) adatai alapján a vertikum önellátottsági szintje kimagasló (140\%), EU-s szinten Lengyelország (158\%) után a második helyet foglalja el, így az ágazatot exportorientáltság jellemzi. A különböző szakágazatok közül a kacsa és a liba esetében az árbevétel mintegy 55-57\%-a származik exportból (Csorbai, 2015). A FAO (2018) által közölt adatok szerint a világ libahús exportja 2006 és 2016 között mintegy 52\%-kal 41,7 ezer tonnáról 63,5 ezer tonnára növekedett, melyből Magyarország 2016-ban 29,2\%-kal (18,5 ezer tonna) részesedett. Az elmúlt években Magyarország libahús exportja fóként Európába irányult, legjelentősebb partnerországai a következők voltak: Németország, Szlovákia, Ausztria, Csehország, Belgium és Franciaország, valamint friss vagy hütött libamájból, illetve más fagyasztott libahúsból és libából előálított élelmezési célra alkalmas vágási melléktermékekből jelentős felvevő piac volt Japán, Kína és Izrael (COMTRADE, 2018).

Az ágazat termékei évtizedek óta keresettek a nemzetközi piacokon, hiszen a vertikum szereplői nemzetközileg elismert, magas hozzáadott értéket képviselő termékeket állítanak elő. Az olyan értékesebb húsrészek iránt, mint a mell vagy a comb szezonálisan (Márton nap, Karácsony) nyilvánul meg nagyobb kereslet (Bogenfürst, 2008; Kozák, 2012; Kozák, 2014). Azonban a liba speciális, prémium terméknek tekinthető, s csak egy szűk réteg fogyasztja. Európában a megtermelt mennyiség 80\%át a németajkú fogyasztók vásárolják meg, ahol a libahús tradicionális, közkedvelt húsféle, így a libacomb és a libamell tekintetében is az ő igényeik a meghatározóak, s keresletük a hazai termelés volumenére is jelentős hatással van (Gippert, 2011; Dobosné, 2013; Szabó, 2013).

Ennek ellenére az ágazat szereplőinek számos kihívással kell szembenéznie. Miután a lúdtermékek kereslete jelentős mértékben függ a fogyasztói szokásoktól, s jellemzően szezonálisan keresik a fogyasztók, így csak kis volumenben értékesíthető. S mivel az árakat a kereslet és a kínálat határozza meg, a tevékenység jövedelme részben attól függ, hogy a termelők milyen áron tudják értékesíteni a termékeiket. Éppen ezért az árutermelés során a versenyképességre kell koncentrálni, s olyan termékeket kell elóállítani, amelyek olyan piacokon is értékesíthetőek, ahol mások is jelen vannak (Avar, 2014; Kállay, 2015; Kozák, 2015).

A libahústermelésben a hizlalás időtartama szerint megkülönböztetünk pecsenyeés húsliba elóállítást. A pecsenyeliba ( 9 hetes) hizlalás során a madarak intenzív növekedését használják ki a termelők, célja a zsírszegény lúd eloállítása. Ezzel szemben a húsliba (14 hetes) jobb paramétereket mutat: a hús-csont aránya kedvezőbb, mint a rövidebb ideig hizlalt libának, valamint a 9 . hetet követően a libamell súlya is jelentős mértékben nő. Ezen túl a vágási veszteség is javul az életkor előrehaladtával, éppen ezért a szakemberek javasolják a lúd továbbnevelését a 9-10. tartási hetet követően. 
Mindezek mellett fontos megjegyezni, hogy az értékesítéskori átlagsúlyt, s ezáltal a hizlalási idő hosszát a feldolgozó határozza meg a piaci igények figyelembevétele mellett (Bódi, 2003; Szőllősi et al., 2014; Bogenfürst, 2017).

Az Agárgazdasági Kutató Intézet (AKI) tesztüzemi adatai alapján megállapítható, hogy bár a libahizlalás nyereséges volt 2010 és 2016 között, a tevékenység jövedelemtermelő képessége jelentős mértékben ingadozott az egyes években (Béládi - Kertész, 2012; Béládi et al., 2017; Szili - Szlovák, 2018). A realizálható jövedelem alakulását az értékesítési árak mellett nagymértékben befolyásolja a termelési költségek alakulása, melyre fóként a takarmányárak volatilitása van hatással (Avar, 2014).

\begin{tabular}{|l|l|l|l|l|l|l|}
\hline Megnevezés & $\mathbf{2 0 1 2}$ & $\mathbf{2 0 1 3}$ & $\mathbf{2 0 1 4}$ & $\mathbf{2 0 1 5}$ & $\mathbf{2 0 1 6}$ & Átlag (2012-2016) \\
\hline Alapanyagköltség & 136,9 & 136,2 & 154,3 & 147,8 & 186,2 & 152,3 \\
\hline Takarmányköltség & 268,2 & 269,7 & 209,6 & 225,2 & 199,2 & 234,4 \\
\hline $\begin{array}{l}\text { Állategészségügyi } \\
\text { költség }\end{array}$ & 10,7 & 13,9 & 15,8 & 18,3 & 11,8 & 14,1 \\
\hline $\begin{array}{l}\text { Egyéb közvetlen válto- } \\
\text { zó költség }\end{array}$ & 21,6 & 24,5 & 23,5 & 18,1 & 17,8 & 21,1 \\
\hline $\begin{array}{l}\text { Személyi jellegü költ- } \\
\text { ség }\end{array}$ & 34,4 & 37,2 & 20,4 & 20,1 & 22,3 & 26,8 \\
\hline $\begin{array}{l}\text { Eszközök értékcsökke- } \\
\text { nési leírása }\end{array}$ & 4,7 & 6,5 & 6,0 & 13,1 & 7,2 & 7,5 \\
\hline Egyéb költségek & 20,5 & 27,9 & 22,7 & 22,6 & 22,2 & 23,2 \\
\hline $\begin{array}{l}\text { Termelési költség össz- } \\
\text { esen }\end{array}$ & 497,2 & 516,2 & 452,3 & 465,2 & 448,7 & 475,9 \\
\hline Termelési érték & 652,4 & 655,4 & 574,5 & 525,9 & 603,5 & 602,3 \\
\hline Nettó jövedelem & 115,2 & 139,2 & 122,2 & 60,7 & 154,8 & 118,4 \\
\hline Jövedelmezöség(\%) & 23,2 & 27,0 & 27,0 & 13,0 & 34,5 & 24,9 \\
\hline
\end{tabular}

1. táblázat: A libahizlalás költség és jövedelemviszonyai a magyarországi meghatározó árutermelő gazdaságok átlagában (2012-2016)

$$
\text { Me.: Ft/kg }
$$

Forrás: Béládi et al., 2017; Szili-Szlovák, 2018

A libahizlalás magyarországi költség- és jövedelemviszonyait mutatja be az 1 . táblázat 2012 és 2016 között a meghatározó árutermelő gazdaságok átlagában. Az adott időszak alatt egy kilogramm libahús előálítása átlagosan 475,9 forintba került, melynek meghatározó részét a takarmány (49\%) és egyéb alapanyagok (alomanyag, napos állat) (32\%) költsége jelenti. Az egyéb közvetlen változó, a személyi jellegű és az egyéb költségek a termelési költség 5-6\%-át, míg az állategészségügyi költség és az eszközök értékcsökkenési leírása annak 2-3\%-át teszi ki. A termelési érték, melyben az árbevétel mellett a támogatás is megjelenik, mint egyéb bevétel, a vizsgált öt évben 
átlagosan $602,3 \mathrm{Ft} / \mathrm{kg}$ volt, értéke az adott időszakban mintegy 7,5\%-kal csökkent. Míg az alapanyagköltségek értéke közel 36\%-kal nőtt az elmúlt évek során, addig a takarmányköltségek értéke 26\%-kal csökkent. Szintén jelentős (35\%) csökkenés volt tapasztalható a személyi jellegü költségek esetében, mely az elmúlt időszak hatékonyságbeli javulására enged következtetni. Ezzel szemben nagymértékben (54\%) nőtt az eszközök értékcsökkenési leírása, melynek oka az elmúlt években végzett felújításokban, fejlesztésekben keresendő.

A tevékenység jövedelme átlagosan $118,4 \mathrm{Ft} / \mathrm{kg}$ volt, melynek értéke a vizsgált időszak során hektikusan változott, aminek oka az értékesítési árak, az alapanyagköltség, valamint a takarmányárak változásában keresendő. A költségarányos jövedelmezőség átlagosan $22,7 \%$ volt, ami azt mutatja, hogy a vizsgált időszakban a libahizlalás gazdasági eredményei kedvezőek voltak.

Az AKI adatbázisa azonban nem tesz különbséget az egyes hasznosítási irányok között, így az előzőekben bemutatott adatok a libahizlalásra általánosságban jellemzőek. Ebből kifolyólag a tanulmány célja a pecsenye- és húsliba hizlalás termelési paramétereinek, valamint költség- és jövedelemviszonyainak vizsgálata eltérő hizlalási idő esetén adott magyarországi telep példáján keresztül.

\section{Anyag és módszer}

A vizsgálat során primer és szekunder adatgyüjtést egyaránt végeztünk. A szekunder adatgyüjtéshez kapcsolódóan ágazati szakanyagok, szakcikkek, valamint hazai adatbázisok adatai kerültek begyűjtésre, s feldolgozásra. A primer adatgyüjtés során egy hazai, víziszárnyas termelésben meghatározó vállalkozás adott telepének pecsenye- (9 hetes) és húsliba (14 hetes) rotációinak elő- és utónevelésére vonatkozó adatai kerültek begyüjtésre a 2012 és 2018 közötti időszakra vonatkozóan. Ennek megfelelően a kapott eredmények a vizsgált telepre vonatkoznak, azonban bizonyos kérdésekben általánosíthatók. Az adatgyüjtés során különböző technológiai és ökonómiai adatok begyüjtésére került sor, majd a termelési paraméterekből származtatott, a baromfiágazatra jellemző naturális hatékonysági mutatókat képeztünk. A primer adatok (technológiai paraméterek, ökonómiai alapadatok) és a származtatott mutatók feldolgozását leíró statisztikai módszerekkel végeztük. A származtatott mutatókat rotációnként, majd az eltérő hizlalási idő átlagában határoztuk meg. A termelési paraméterek leíró statisztikai módszerekkel történő elemzését követően a független kétmintás t-próba alkalmazásával megvizsgáltuk, hogy mely tényezők között mutatható ki szignifikáns eltérés. A t-próba alkalmazhatóságát F-próbával ellenőriztük, amely alapján eldönthető, hogy a két minta azonos varianciájú sokaságból származik-e. Amennyiben szignifikáns eltérés tapasztalható, úgy Welch-próba végzése ajánlott. Ezt követően 
meghatároztuk a 14 hetesen vágott lúd esetében tapasztalható többletráfordítással elérhető eredményváltozást a 9 hétig nevelt madár ráfordítás szintjéhez képest (pótlólagos hatékonyság).

\section{Eredmények}

A vizsgált telepen az adott időszakban 6 eltérő alapterületű istállóban folyt a termelés. A napos libákat magasabb telepítési sűrűség mellett előnevelő istállókba telepítik, majd jellemzően három hét elteltével utónevelő istállókba helyezik át őket. Az épületekhez egyenként mintegy $2000 \mathrm{~m}^{2}$ alapterületű kifutó is tartozik. Az istállók több mint 40 éve épültek, azonban az évek során felújították azokat, s légbeejtő ablakok, valamint szellőztető rendszer került kiépítésre. Az etetést öt istállóban tányéros alsópályás etetőrendszerrel oldják meg, míg egy épület felsőpályás etetőrendszerrel rendelkezik, ahol hordós etetés zajlik. A vizsgált időszakban az alkalmazott fajta a Golden Goose White volt. A húshasznosítású lúdfajták és hibridek között Magyarországon - a Lippitsch és a Hortobágyi fehér lúd mellett - ez az egyik legelterjedtebb genotípus az elmúlt évek adatai alapján (Kozák - Szász, 2016).

A 2. táblázat a pecsenye- és a húsliba elóállítás termelési mutatóinak a telepre jellemző alakulását mutatja be. A pecsenyelibát jellemzően 21,8 napig tartották előnevelőkben, míg az utónevelés hossza 40,4 nap volt, így a nevelési idő átlagosan 62,2 nap. Ezzel szemben a húsliba esetében a nevelési idő átlagosan 99 nap volt, melyből az előnevelés 25,5, míg az utónevelés 73,5 napot tesz ki. Az elhullás mértéke az előnevelés során közel azonos, 3,8\%, illetve 4\%, ugyanakkor az utónevelésben 0,8\%-ponttal magasabb elhullás volt tapasztalható a pecsenyeliba hizlalásnál. Jelen esetben ez nem feltétlen hozható összefüggésbe az eltérő hizlalási idővel, inkább az eltérő környezeti és állategészségügyi tényezőkre vezetnénk vissza. A húsliba előállítás fajlagos takarmányfelhasználása (Feed Conversion Ratio, FCR) 3,8 és 4,1 kg/kg között alakult, átlagosan $4,0 \mathrm{~kg} / \mathrm{kg}$ volt a vizsgált rotációk esetében. Ezzel szemben a pecsenyelibánál az FCR értéke kedvezőbb, átlagosan 2,9 kg/kg volt. A vizsgált időszakban a pecsenyeliba $4,9 \mathrm{~kg} / \mathrm{db}$ átlagsúllyal került értékesítésre, azonban ennek értéke az egyes rotációk esetén 4,5 és $5,5 \mathrm{~kg} / \mathrm{db}$ között változott. Ezzel szemben a húsliba átlagosan 5,6 kg/db átlagsúllyal került vágásra, melynek értéke 5,4 és 5,9 kg/db között alakult. Az egyes rotációk esetén tapasztalható különbség oka az évszakok és a vágóhíd igényeinek változása, mindkét hasznosítási irány esetében. Az eredmények alapján az is megállapítható, hogy az átlagos napi súlygyarapodás értéke jelentősen (39\%-kal) kedvezőbb a pecsenyeliba elóállítás esetében. 


\begin{tabular}{|l|l|l|l|l|}
\hline \multicolumn{1}{|c|}{ Termelési mutató } & Me. & $\begin{array}{c}\text { Pecsenyeliba } \\
(9 \text { hetes }) \\
(n=5)\end{array}$ & $\begin{array}{c}\text { Húsliba } \\
(14 \text { hetes }) \\
(n=4)\end{array}$ & $\begin{array}{c}\text { Eltérés } \\
(14 \text { hetes }-9 \text { hetes })\end{array}$ \\
\hline Elhullás (előnevelés) & $\%$ & 3,77 & 3,96 & 0,19 \\
\hline Elhullás (utónevelés) & $\%$ & 4,07 & 3,24 & $-0,83$ \\
\hline $\begin{array}{l}\text { Fajlagos } \\
\text { takarmányfelhasználás }\end{array}$ & $\mathrm{kg} / \mathrm{kg}$ & 2,92 & 3,99 & $1,07^{*}$ \\
\hline Értékesítéskori átlagsúly & $\mathrm{kg} / \mathrm{db}$ & 4,93 & 5,64 & $0,71^{*}$ \\
\hline Nevelési idő & $\mathrm{nap}$ & 62,20 & 99,00 & $36,80^{*}$ \\
\hline Átlagos napi súlygyarapodás & $\mathrm{g} / \mathrm{nap}$ & 79,38 & 57,12 & $-22,26^{*}$ \\
\hline
\end{tabular}

\section{2. táblázat: A pecsenye- és húsliba hizlalás naturális hatékonysági mutatói}

(2012-2018)

${ }^{1}$ A számított értékek az érintett istállók alapterületeinek összegére vonatkoznak

${ }^{2}$ A számított értékek az érintett istállók alapterületeinek és a hozzájuk tartozó kifutók területének összegeire vonatkoznak

$$
{ }^{*} \mathrm{p}<0,05
$$

Forrás: saját számitás a vállalkozás adatai alapján

Az F-próba eredményei alapján megállapítható, hogy az elhullások értékének varianciája nem azonos, így ezen mutatók esetében Welch-próbát végeztünk. A próba értékei szerint e paraméterek szignifikancia szintje nagyobb, mint 0,05, tehát a hasznosítási irányok tekintetében az elhullás mértékében nincs statisztikailag igazolható különbség. A többi termelési mutató értékei azonos varianciájúak, így azok esetében alkalmazható a t-próba. A fajlagos takarmányfelhasználás, az értékesítéskori átlagsúly, a nevelési idő, valamint az átlagos napi súlygyarapodás esetén szignifikáns $(\mathrm{p}<0,05)$ eltérés mutatható ki.

A 3. táblázat a vizsgált telep átlagos, fajlagos költség- és jövedelemviszonyait mutatja be a különböző hasznosítási irányok esetén. A pecsenyeliba előállításának költsége a vizsgált telepen átlagosan $447 \mathrm{Ft} / \mathrm{kg}$ volt, amely a legjobb esetben $415 \mathrm{Ft} / \mathrm{kg}$, míg a legrosszabb rotációban is csak $489 \mathrm{Ft} / \mathrm{kg}$ volt. Ezzel szemben a húsliba önköltsége átlagosan $455 \mathrm{Ft} / \mathrm{kg}$ (min: $351 \mathrm{Ft} / \mathrm{kg}$, max: $518 \mathrm{Ft} / \mathrm{kg}$ ) volt. 


\begin{tabular}{|c|c|c|c|c|c|}
\hline Megnevezés & $\begin{array}{c}\text { Pecsenyeliba } \\
\begin{array}{c}(9 \text { hetes }) \\
(n=5)\end{array}\end{array}$ & (\%) & $\begin{array}{c}\text { Húsliba } \\
\text { (14 hetes) } \\
(n=4)\end{array}$ & (\%) & $\begin{array}{c}\text { Eltérés } \\
(14 \text { hetes }-9 \text { hetes })\end{array}$ \\
\hline Anyagjellegű költségek & 421,43 & 94,2 & 416,54 & 91,6 & $-4,88$ \\
\hline Napos állat & 214,30 & 47,9 & 212,33 & 46,7 & $-1,96$ \\
\hline Takarmány & 176,41 & 39,4 & 168,79 & 37,1 & $-7,62$ \\
\hline Energia & 3,38 & 0,8 & 6,78 & 1,5 & 3,41 \\
\hline Alomanyag & 12,05 & 2,7 & 7,27 & 1,6 & $-4,78$ \\
\hline Állatgyógyszer & 3,89 & 0,9 & 5,79 & 1,3 & 1,90 \\
\hline Igénybevett szolgáltatások ${ }^{1}$ & 9,38 & 2,1 & 9,38 & 2,2 & 0,46 \\
\hline Egyéb $b^{2}$ & 2,03 & 0,5 & 5,74 & 1,3 & 3,72 \\
\hline Személyi jellegű költségek & 16,18 & 3,6 & 24,77 & 5,4 & 8,59 \\
\hline Értékcsökkenési leírás & 4,90 & 1,1 & 4,90 & 1,1 & 0,00 \\
\hline Segédüzemági költség & 1,72 & 0,4 & 6,12 & 1,3 & 4,40 \\
\hline Általános költségek & 3,18 & 0,7 & 2,30 & 0,5 & $-0,88$ \\
\hline Termelési költség összesen & 447,41 & 100,0 & 454,64 & 100,0 & 7,23 \\
\hline Értékesítési ár & 534,00 & - & 583,33 & - & 49,33 \\
\hline Nettó jövedelem & 86,59 & - & 128,70 & - & 42,11 \\
\hline $\begin{array}{l}\text { Költségarányos jövedelme- } \\
\text { zőség }(\%)\end{array}$ & 19,54 & - & 31,23 & - & 11,69 \\
\hline
\end{tabular}

3. táblázat: A pecsenye- és húsliba előállítás költség- és jövedelemviszonyai a vizsgált rotációk esetében

Me.: Ft/kg

'állategészségügyi- és állattenyésztési szolgáltatások, hulladékmegsemmisítés, szállítás, rakodás költsége, egyéb igénybe vett szolgáltatások stb.

2alkatrészek, javítás és karbantartás, munkaruha, tisztítószerek stb.

Forrás: saját számitás a vállalkozás adatai alapján

Az eredmények alapján megállapítható, hogy mindkét hasznosítási irány esetében az anyagjellegü költségek teszik ki a termelési költségek legnagyobb részét (9194\%-át), melyet a napos állat és a takarmány költsége határoz meg. Az energia, az állatgyógyszer, az igénybevett szolgáltatások, az alomanyag, valamint az egyéb anyagjellegü költségek kevésbé meghatározó költségtételek, arányuk az anyagjellegü költségeken belül mindössze 1-3\%. Az alomanyag költségét jellemzően a telepített napos állat mennyisége és az időjárás határozzák meg, melyek jelentős mértékben befolyásolják a felhasznált, alomanyagként alkalmazott szalma mennyiségét. A személyi jellegű költségek a termelési költségnek átlagosan 4-5\%-át, míg az értékcsökkenési leírás annak 1\%-át teszi ki. A segédüzemági és az általános költségek (biztosítási, hatósági díjak és igazgatási költségek stb.) aránya elenyésző, jellemzően 1-1,5\%. 
A vizsgált vállalkozás esetében a pecsenyeliba értékesítési ára 500 és 550 Ft/kg között változott, míg a húslibát jellemzően 550 és 600 Ft/kg áron értékesítették az adott időszakban. Ennek alakulása követi az országos átlagok (Béládi et al., 2017; KSH, 2018; Szili - Szlovák, 2018) tendenciáját. A vállalkozás esetében realizált értékesítési ár mellett a tevékenység jövedelme a pecsenyeliba esetén 61 és $105 \mathrm{Ft} / \mathrm{kg}$ között alakult, átlagosan $87 \mathrm{Ft} / \mathrm{kg}$ volt. Ezzel szemben a húsliba termelés jövedelme átlagosan $129 \mathrm{Ft} / \mathrm{kg}$ volt, melynek értéke 82 és $199 \mathrm{Ft} / \mathrm{kg}$ között változott. Ez alapján az is látható, hogy a vizsgált időszakban a pecsenyeliba hizlalás költségarányos jövedelmezősége átlagosan 19,5\% volt, míg a húsliba esetén ez az érték átlagosan 31,2\% volt. Tehát a tevékenység mindkét hasznosítási irány esetében jövedelmező volt, azonban annak mértéke az egyes években eltérően alakult.

Mindezek alapján az is megállapítható, hogy a telep esetében a termelési költségek a hasznosítási iránytól függően átlagosan 4-6\%-kal kedvezőbbek, mint a meghatározó árutermelő gazdaságok országos átlaga (lásd 1. táblázat), az értékesítési ár azonban a pecsenyeliba esetén 30 forinttal elmarad az országos átlagtól, míg a húsliba esetén 21 forinttal meghaladja azt. Emellett a telepen mind a pecsenye, mind a húsliba előállítás költségarányos jövedelmezősége (19-31\%) a meghatározó árutermelö gazdaságok átlagához (25\%) hasonlóan alakul. Az F-próbát és a Welch-próbát a termelési költség, az árbevétel, valamint a nettó jövedelem esetében is elvégeztük, azonban a próbák eredményei alapján a hasznosítási irányok tekintetében a vizsgált mutatók esetén nincs statisztikailag igazolható különbség. Mindez alapvetően a viszonylag alacsony elemszámra, illetve az adatok jelentősebb szórására vezethető vissza. Utóbbira az egyes évek között megfigyelhető input-output árak ingadozása is befolyásolja.

A 4. táblázat a 9 hetes és a 14 hetes végtermék előálításának átlagos hatékonysági mutatóit, illetve a kettő közötti pótlólagos hatékonyságot mutatja be. Megvizsgálva a fajlagos takarmányfelhasználást megállapítható, hogy értéke a 9. és 14. hét között jelentősen, 11,4 kg/kg-ra nő, ezáltal romlik a húsliba elóállítás esetén tapasztalható FCR értéke a 9. élethéthez képest. Az eredmények alapján az is megfigyelhető, hogy amíg a 9 hetes nevelési idő alatt 1 kg takarmány felhasználásával valamivel több, mint $0,3 \mathrm{~kg}$ élősúly állítható elő, addig a továbbnevelési időszakban (9-14. hét) ez a többlethozam mindössze $0,1 \mathrm{~kg}$. Ennek hátterében alapvetően az átlagos napi súlygyarapodás csökkenése áll, hiszen látható, hogy míg az átlagos napi súlygyarapodás az első 9 hétben 79,38 g/nap, addig ez az érték a továbbhizlalás időszakában jelentős mértékben, mintegy 19,27 g/nap értékre csökken. Ezzel szemben a napi takarmányfelvétel minimális mértékben változik, ami azt jelenti, hogy a hizlalási idő előrehaladtával a ludak a felvett takarmány egyre nagyobb hányadát fordítják életfenntartó energiára, szemben a súlygyarapodással.

Megállapítható továbbá, hogy az ökonómiai mutatók egy napra és egy madárra, valamint egy kilogrammra vetített értéke a továbbtartással csökken, ugyanakkor az egységnyi termelési költséggel elérhető árbevétel és nettó jövedelem kedvezőbb ér- 
téket mutat. Ez annak tudható be, hogy a 9. és a 14. hét között egy forint többlet termelési költséggel (pótlólagos ráfordítással) 6,81 Ft többlet árbevétel, illetve 5,81 Ft többletjövedelem realizálható, ami jelentősen meghaladja a 0-9. hét között realizálható átlagos hatékonyságot.

\begin{tabular}{|l|c|c|c|c|}
\hline \multicolumn{1}{|c|}{ Megnevezés } & Me. & 0-9. hét & 9-14. hét & 0-14. hét \\
\hline Napi takarmányfelvétel madaranként & $\mathrm{g} / \mathrm{nap} / \mathrm{db}$ & 230,99 & 220,48 & 227,43 \\
\hline Átlagos napi súlygyarapodás & $\mathrm{g} / \mathrm{nap}$ & 79,38 & 19,27 & 57,12 \\
\hline Fajlagos takarmányfelhasználás & $\mathrm{kg} / \mathrm{kg}$ & 2,92 & 11,44 & 3,99 \\
\hline 1 kg takarmánnyal elóállítható élötömeg & $\mathrm{kg} / \mathrm{kg}$ & 0,34 & 0,09 & 0,25 \\
\hline 1 napra jutó árbevétel madaranként & $\mathrm{Ft} / \mathrm{db} / \mathrm{nap}$ & 42,31 & 17,86 & 32,80 \\
\hline $\begin{array}{l}\text { 1 napra jutó termelési költség madaran- } \\
\text { ként }\end{array}$ & $\mathrm{Ft} / \mathrm{db} / \mathrm{nap}$ & 35,41 & 9,73 & 25,37 \\
\hline $\begin{array}{l}\text { 1 napra jutó nettó jövedelem madaran- } \\
\text { ként }\end{array}$ & $\mathrm{Ft} / \mathrm{db} / \mathrm{nap}$ & 6,89 & 8,13 & 7,43 \\
\hline 1 napra jutó árbevétel kg-ként & $\mathrm{Ft} / \mathrm{kg} / \mathrm{nap}$ & 8,59 & 1,34 & 5,81 \\
\hline 1 napra jutó termelési költség kg-ként & $\mathrm{Ft} / \mathrm{kg} / \mathrm{nap}$ & 7,19 & 0,20 & 4,51 \\
\hline 1 napra jutó nettó jövedelem kg-ként & $\mathrm{Ft} / \mathrm{kg} / \mathrm{nap}$ & 1,40 & 1,14 & 1,30 \\
\hline $\begin{array}{l}\text { 1 Ft termelési költséggel elérhetö } \\
\text { árbevétel }\end{array}$ & $\mathrm{Ft} / \mathrm{Ft}$ & 1,20 & 6,81 & 1,31 \\
\hline $\begin{array}{l}\text { 1 Ft termelési költséggel elérhető nettó } \\
\text { jövedelem }\end{array}$ & $\mathrm{Ft} / \mathrm{Ft}$ & 0,20 & 5,81 & 0,31 \\
\hline
\end{tabular}

4. táblázat: Átlagos és pótlólagos hatékonyság

${ }^{1} \mathrm{Az}$ adatsorok átlagadataiból kalkulált értékek.

Forrás: saját számitás a vállalkozás adatai alapján

\section{Következtetések, javaslatok}

A vizsgált telep technológiai színvonala mellett, a pecsenyeliba elöálítása során 62 napos nevelési időszak alatt 4,9 kg/db átlagsúly érhető el, az elő- és utónevelés során mintegy 4-4\%-os elhullás, átlagosan 2,9 kg/kg fajlagos takarmányfelhasználás mellett. Ezzel szemben a naturális hatékonysági mutatók értékei a 14 hetes korban vágott lúd esetében kedvezőtlenebbek, hiszen a hosszabb hizlalási idő esetén 99 nap alatt elérhető $5,6 \mathrm{~kg} / \mathrm{db}$ értékesítéskori átlagsúlyhoz $4,0 \mathrm{~kg} / \mathrm{kg}$ fajlagos takarmányfelhasználás társul, $s$ a napi súlygyarapodás is romlik az idő előrehaladtával.

A termelési paraméterekben tapasztalható különbségek ellenére a húsliba elöállítás költség- és jövedelemviszonyai mégis kedvezőbbek, mint a pecsenyeliba esetén. Míg egy kilogramm pecsenyeliba előállítása átlagosan 447 forintba került, addig a 
húsliba elóállításának költsége $455 \mathrm{Ft} / \mathrm{kg}$. A nevelési időtől függetlenül a termelési költségek 91-94\%-át az anyagjellegű költségek jelentik. Ezen belül meghatározó a napos állat és a takarmány költsége. Miután a vállalkozás által realizált értékesítési árak nagyobb mértékben emelkednek a húsliba elóállítása esetében, mint a termelési költségek, így a hosszabb hizlalási idő mellett mintegy 42 forinttal magasabb nettó jövedelem érhető el kilogrammonként, s a költségarányos jövedelmezőség is kedvezőbben alakul. Mindez azt jelenti, hogy a 9 hetes végtermék elöálításához viszonyítva a 14 hetes liba hizlalása mellett realizálható többlet árbevétel meghaladja az annak előállításához szükséges többletráfordítást (pótlólagos termelési költséget), így növekszik az elérhető a termékegységre eső jövedelem.

\section{Köszönetnyilvánítás}

A kutatás a „Tehetségből fiatal kutató” - a kutatói életpályát támogató tevékenységek a felsőoktatásban címü, EFOP-3.6.3-VEKOP-16-2017-00007 azonosító számon nyilvántartásba vett pályázati támogatás keretében valósult meg.

\section{Hivatkozott források}

[1.] Avar L. (2014): Liba és kacsa - realitás szárnyán. Magyar Mezőgazdaság, 69. évf., 46. sz., 26-27. o.

[2.] AVEC (2017): Annual report - 2017. Association of Poultry Processors and Poultry Trade in the EU Countries. Brussels, Belgium. 38. p. Letöltés dátuma: 2018. január 16. http://www.avec-poultry.eu/system/files/archive/ new-structure/avec/Annual_Report/2017/AVEC\%202017\%20-\%20BAT. pdf

[3.] Béládi K. - Kertész R. (2012): A főbb mezőgazdasági ágazatok költség- és jövedelemhelyzete 2011. Agrárgazdasági Kutató Intézet, Budapest, 138-139. o.

[4.] Béládi K. - Kertész R. - Szili V. (2017): A főbb mezőgazdasági ágazatok költség- és jövedelemhelyzete 2013-2015. Agrárgazdasági Kutató Intézet, Budapest, 148. o. http://dx.doi.org/10.7896/ai1704

[5.] Bogenfürst F. (2008): A víziszárnyas ágazat helyzete és jövőbeni kilátásai Magyarországon. Állattenyésztés és takarmányozás, 57. évf., 5. sz., 415-423. o. 
[6.] Bogenfürst F. (2017): Lúdtenyésztők kézikönyve. FORUM 2017, Editrice Universitaria Udinese, 340 p. ISBN 9788832830477

[7.] Bódi L. (2003): A pecsenye- és húslúd vágótulajdonságai és húsminősége. Baromfi, 7. évf., 3. sz., 14-19. o.

[8.] Comtrade (2018): UN Comtrade Database. http://comtrade.un.org/

[9.] Csorbai A. (2015): A magyar baromfiipar és az ágazatok helyzete, lehetőségei, versenyképessége, avagy előre vagy hátra? Baromfi Hírmondó - Az Agrofeed Kft. baromfi hírlevele, 22 évf., 3. sz., 5-7. o.

[10.] Dobosné Németh O. (2013): Sötét jövőt jósolok a lúdágazatnak. In: Szerkesztőségi összeállítás: A víziszárnyas-ágazat jelene és jövőképe Csökkenteni kell a libaelőállítás volumenét. Baromfiágazat, 13. évf., 4. sz., 49-53. o.

[11.] FAO (2018): Food and Agriculture Organization of the United Nations adatbázisa. http://www.fao.org/faostat/en/\#home

[12.] Gippert B. (2011): Megmaradni libásnak... Baromfiágazat, 11. évf., 3. sz., 13-15. o.

[13.] Kállay B. (2015): Piacvezető vállalkozás Kelet-Magyarországon. Baromfiágazat, 15. évf., 3. sz., 48-52. o.

[14.] Kozák J. (2012): A világ libahústermelésének és -kereskedelmének alakulása az elmúlt évtizedekben. Gazdálkodás, 56. évf., 6. sz., 512-521. o.

[15.] Kozák J. (2014): Lúdtenyésztők szakmai konferenciája. Baromfiágazat, 14. évf., 4. sz., 70-71. o.

[16.] Kozák J. (2015): Kiskunfélegyházi Libafesztivál - konferenciával. Baromfiágazat, 15. évf., 4. sz., 76-77. o.

[17.] Kozák J. - Szász S. (2016): Mai irányok a víziszárnyas-tenyésztésben. Állattenyésztés és takarmányozás, 65. évf., 4. sz., 47-73. o.

[18.] KSH (2018): Központi Statisztikai Hivatal adatbázisa. http://www.ksh.hu/ docs/hun/xstadat/xstadat_eves/i_qsma003.html

[19.] Szabó M. (2013): Remélem van jelenünk és jövőnk is. In: Szerkesztőségi összeállítás: A víziszárnyas-ágazat jelene és jövőképe - Csökkenteni kell a libaelőállítás volumenét. Baromfiágazat, 13. évf., 4. sz., 49-53. o.

[20.] Szili V. - Szlovák S. (2018): A fóbb mezőgazdasági ágazatok költség- és jövedelemhelyzete 2016. Agrárgazdasági Kutatóintézet, 127. o. http:// dx.doi.org/10.7896/ai1803 
[21.] Szőllősi L. - Szűcs I. - Nábrádi A. (2014): Economic issues of broiler production length. Ekonomika Poljoprivrede / Economics Of Agriculture, 61. évf. 3. sz., 633-646. o. https://doi.org/10.5937/ekoPolj1403633S

\section{Szerzők:}

\section{Molnár Szilvia}

doktorjelölt

Debreceni Egyetem Gazdaságtudományi Kar

E-mail: molnar.szilvia@econ.unideb.hu

\section{Dr. Szőllősi László}

egyetemi docens

Debreceni Egyetem Gazdaságtudományi Kar

E-mail: szollosi.laszlo@econ.unideb.hu 